\title{
Patterns of plant species richness and composition in deciduous oak forests in relation to environmental drivers
}

\author{
M. Slezák ${ }^{1,2}$ and I. Axmanová3 \\ 1Department of Biology and Ecology, Faculty of Education, Catholic University, Hrabovská cesta 1, SK-034 01 \\ Ružomberok, Slovak Republic \\ 2Institute of Botany, Slovak Academy of Sciences, Dúbravská cesta 9, SK-845 23 Bratislava, Slovak Republic. \\ Corresponding author: E-mail: slezak.miso@gmail.com \\ ${ }^{3}$ Department of Botany and Zoology, Masaryk University, Kotlářská 2, CZ-611 37 Brno, Czech Republic
}

Keywords: Alpha diversity, Bryophytes, Deciduous oak forests, Light conditions, Soil chemistry, Topography, Vascular plants.

\begin{abstract}
Local plant species richness and composition may vary across habitats and between plant taxonomic groups within temperate deciduous forests. Multi-taxon approach is therefore needed to provide a more detailed insight into determinants affecting vegetation structure. Fifty-four deciduous oak-dominated vegetation plots $(20 \mathrm{~m} \times 20 \mathrm{~m})$ were sampled across central Slovakia (Štiavnické vrchy Mts) in order to study the effect of environmental (soil, light, topographic) factors on species richness and composition patterns of two main assemblages of understorey layer (herb-layer vascular plants and ground-dwelling bryophytes). The number of recorded herb-layer vascular plants and ground-dwelling bryophytes was 12-48 (mean 28) and 0-11 (mean 4) species per plot, respectively. Generalized linear model revealed that species richness of herb-layer vascular plants was driven by canopy openness, altitude, soil $\mathrm{pH} /$ base saturation gradient and plant-available phosphorus. Canopy openness and heat load index accompanied by soil $\mathrm{pH} /$ base saturation gradient determined changes of the ground-dwelling bryophyte richness. Canonical Correspondence Analysis identified soil pH/base saturation gradient, canopy openness, soil silt and topography related predictors (altitude, slope, radiation) as the main drivers of the herb-layer vascular plant compositional variability. Species composition variation of ground-dwelling bryophytes was controlled by radiation and canopy openness.
\end{abstract}

Abbreviations: CCA - Canonical Correspondence Analysis, GLM - Generalized Linear Model, PCA - Principal Component Analysis

Nomenclature: Marhold and Hindák (1998) for vascular plants and bryophytes.

\section{Introduction}

Biodiversity research has strived to uncover the underlying mechanisms in functioning of ecosystems for a long time (Tilman 2000). The substantial part of plant species richness in temperate deciduous forests is concentrated to the understorey layer that has been shown to be relevant for maintenance of their functions and structure (Gilliam 2007). Its division into taxonomic or plant functional groups is important for a deeper understanding of potential factors controlling species richness patterns (Pausas and Austin 2001), as final response of the whole understorey can hide contrasting trends of particular plant groups. Two main assemblages of understorey layer including herb layer vascular plants and ground-dwelling bryophytes coexist in habitats with various environmental qualities, but their contribution to total plant species richness of temperate forests is unequal, as the number of herb species greatly exceeds the number of bryophytes (Whigham 2004, Gilliam 2007). Their species compositional and richness patterns at local scale significantly vary along an environmental gradient that represents a more complex phenomenon integrating mainly edaphic, light and topographic conditions. The response of herb layer vascular plants and ground-dwelling bryophytes to these environmental drivers may be considerably different (Ingerpuu et al. 2003, Bacaro et al. 2008), as they differ in several fundamental traits including the pathways of nutrient and water uptake (Brown and Bates 1990, Proctor and Tuba 2002, Cornelissen et al. 2007).

Previous studies stressed the role of habitat productivity (i.e., soil $\mathrm{pH}$ and limiting nutrients) as one of the most important edaphic factors affecting understorey compositional and richness changes (Dupré et al. 2002, Härdtle et al. 2003, Schuster and Diekmann 2005, Hofmeister et al. 2009, Axmanová et al. 2012). Its physiological relevance for plant establishment and growth results from either poor availability of nutrients and aluminium toxicity on very acidic soils, or low solubility of some essential elements on extremely basic soils (Andersson 1988, Marschner 1991, Tyler 2003). These physiological limits suggest a hump-shaped curve of species richness-soil productivity interaction. In addition, interspecific competition reduces species richness in productive habitats, but its effect is gradually released towards nutrient-poor habitats. The most commonly limiting elements identified in the temperate region are nitrogen and phosphorus (Attiwill and Adams 1993, Hrivnák et al. 2015). The higher concentration of nitrogen usually causes species loss of vascular plants (Dupré et al. 2002), whereas the effect of phospho- 
rus has shown inconsistent results (see e.g., Dumortier et al. 2002, Hofmeister et al. 2009). These contrasting responses are most often functions of diverse phosphorus pools among study sites, but potential role may also be played by covariant factors affecting the supply, chemical form and availability of nutrients (e.g., soil pH, chemistry of bedrock). Although bryophytes and vascular plants show the same requirements on spectrum of nutrients, many bryophytes are indifferent to the soil nutrient/acidity complex and are less dependent on their availability in soil substrate (Bates 2009). Much lower quantitative requirements of bryophytes on nutrients, their ability to directly absorb dissolved nutrients from atmosphere (Cornelissen et al. 2007) and effective stress avoidance at marginal parts of soil pH gradient (Büscher et al. 1990, Bates 1992) suggest limited overlap with vascular plants in resource niche and therefore minimal competitive relationship in nutrient uptake.

The importance of light affecting species composition and richness of understorey layer depends on analysed forest vegetation types (Härdtle et al. 2003), but recent research conducted across various temperate forests emphasized the increasing herb layer species richness along gradient of light availability (Tinya et al. 2009, Vockenhuber et al. 2011). This pattern suggests a limitation on the number of shade-tolerant vascular plants (Ewald 2008, Axmanová et al. 2012). Rarely reported absence of significant species richness-light relationship (e.g., Augusto et al. 2003) can be most often explained by the confounding effect of soil nutrient-related parameters, organic matter or forest management practices. Competitive light asymmetry induced by larger stature of vascular plants obviously creates shaded conditions for ground-dwelling bryophytes growing underneath. Bryophyte sensitivity on light reduction is also indicated through the negative linkage between covers of bryophytes and herb-layer vascular plants (e.g., Ingerpuu et al. 2003). In spite of generally low light compensation point of bryophytes (Proctor 1981), light is undoubtedly an essential limiting factor for their growth.

Topography affects high environmental heterogeneity, which in turn determines the quantity of available niches with repercussions on plant species diversity (see heterogeneity-diversity hypothesis; Lundholm 2009). Micro-relief and habitat configuration-related variables (e.g., aspect, slope inclination, radiation) strongly affect forest understorey through their effects on soil xericity and organic matter content (Sabatini et al. 2014). Vegetation patterns are also controlled by an altitudinal gradient which does not represent an ecological factor per se. Its impact is ultimately caused by abiotic forces (i.e., changes in a set of site-specific conditions) and stochastic processes (Hrivnák et al. 2014).

The relevance of edaphic, light and topographic factors has been frequently discussed in relation to forest stands with mixed overstorey composition (e.g., Härdtle et al. 2003, Vockenhuber et al. 2011). Broad-leaved tree species, which are found in these ecosystems, are characterized by high variability of light transmission, litter quality and quantity (which affects also the ability to acidify the upper soil mineral horizons) and below-ground competition for water and soluble nutrients (Augusto et al. 2002, Barbier et al. 2008). Forest overstorey thus creates conspicuous environmental filter for the understorey layer and thereby may confound the observed patterns of species richness related to environmental drivers. Oak forests of temperate Central European regions provide a good reference to study the environment-vegetation relationships because they are dominated by oak species with relatively constant effect on understorey and are able to settle a wide range of habitats and environmental gradients. In addition, they have a well-developed multi-layered structure where herb-layer vascular plants and ground-dwelling bryophytes form an important part of the plant species assemblage (Ellenberg 2009).

We studied deciduous oak forests in central part of Slovakia and by focusing on their herb-layer vascular plants and ground-dwelling bryophytes, we asked two main questions: (i) what are the environmental drivers of plant species richness and (ii) which set of environmental variables explains most of the variation in species composition?

\section{Materials and methods}

\section{Study area}

We studied oak forest vegetation in the Štiavnické vrchy Mts (central Slovakia; $48^{\circ} 12^{\prime}-48^{\circ} 35^{\prime} \mathrm{N} ; 18^{\circ} 32^{\prime}-19^{\circ} 05^{\prime} \mathrm{E}$; Fig. 1) in 2008 and 2009. This volcanic mountain range is situated in the contact area of the Western Carpathian and Pannonian phytogeographic region. The geological substrate consists mainly of andesites and rhyolites, rarely of conglomerates or shales. The diverse base status of the bedrock is reflected in a wide range of soil types with various chemical and physical properties (Table 1). In order to achieve a relatively constant impact of overstorey on vascular plant species and bryophytes, our field research was performed on sites with dominance (at least $50 \%$ cover in the tree layer) of an oak species native to this region, namely Quercus petraea agg. (incl. $Q$. dalechampii, $Q$. polycarpa, $Q$. petraea s. str.) and Q. cerris. Only homogeneous stands with mature trees and no signs of recent disturbances were chosen to minimise human impacts on structure and species composition. To cover vegetation and ecological variation in the study area, the sampling was carried out in acidophilous and thermophilous oak forests, including broad-leaved mixed oak-hornbeam forests (phytosociological classes Querco-Fagetea and Quercetea robori-petraeae).

\section{Field sampling and laboratory analysis}

We sampled 54 vegetation plots with a constant size of $20 \mathrm{~m} \times 20 \mathrm{~m}$. They were scattered relatively evenly over the study area to cover a wide range of geological and geomorphological conditions. In each plot, we recorded the total plant species list along with their percentage cover using the standard European phytosociological approach. The species taxonomy and nomenclature was unified according to the checklist of Marhold and Hindák (1998). The plant species were subsequently divided into herb-layer vascular 
Table 1. Descriptive statistic and Spearman correlations between the species richness of plant functional groups (herb-layer vascular plants, ground-dwelling bryophytes) and environmental variables.

\begin{tabular}{|c|c|c|c|c|c|}
\hline \multirow[b]{2}{*}{ Variable } & \multirow[b]{2}{*}{ Mean $\pm \mathrm{SD}$} & \multirow[b]{2}{*}{ Min } & \multirow[b]{2}{*}{ Max } & \multicolumn{2}{|c|}{ Species richness } \\
\hline & & & & $\begin{array}{c}\text { Herb-layer } \\
\text { vascular plants }\end{array}$ & $\begin{array}{c}\text { Ground- } \\
\text { dwelling } \\
\text { bryophytes }\end{array}$ \\
\hline \multicolumn{6}{|l|}{ Topographic } \\
\hline Altitude (m) & $559 \pm 118$ & 330 & 805 & $0.35 *$ & n.s. \\
\hline Heat load (topographic index) & $0.86 \pm 0.13$ & 0.38 & 0.98 & n.s. & $-0.31^{*}$ \\
\hline Radiation (topographic index) & $0.86 \pm 0.13$ & 0.37 & 0.97 & n.s. & n.s. \\
\hline Slope $\left(^{\circ}\right)$ & $23.7 \pm 8.2$ & 5.0 & 45.0 & n.s. & n.s. \\
\hline \multicolumn{6}{|l|}{ Edaphic } \\
\hline Soil pH $\left(\mathrm{H}_{2} \mathrm{O}\right)$ & $5.0 \pm 0.8$ & 3.8 & 6.7 & $0.63^{* * *}$ & $-0.53 * * *$ \\
\hline Total Carbon (\%) & $5.44 \pm 2.11$ & 2.33 & 12.87 & n.s. & n.s. \\
\hline Total Nitrogen $(\%)$ & $0.34 \pm 0.15$ & 0.10 & 0.81 & $0.38^{* *}$ & $-0.34 *$ \\
\hline Soil Phosphorus (mg.kg-1) & $31.5 \pm 27.0$ & 2.1 & 130.9 & $0.56^{* * *}$ & $-0.44 * * *$ \\
\hline Soil Potassium (mg.kg-1) & $278 \pm 131$ & 107 & 810 & $0.45^{* * *}$ & $-0.54 * * *$ \\
\hline Soil Calcium (mg.kg-1) & $1124 \pm 1030$ & 12 & 4139 & $0.59 * * *$ & $-0.41 * *$ \\
\hline Soil Magnesium (mg.kg-1) & $207 \pm 149$ & 12 & 647 & $0.56^{* * *}$ & $-0.44 * * *$ \\
\hline Soil Aluminium (mg.kg-1) & $137 \pm 189$ & 0 & 702 & $-0.52 * * *$ & $0.41 * *$ \\
\hline Soil sand $(\%)$ & $35.6 \pm 12.3$ & 5.4 & 60.9 & n.s. & n.s. \\
\hline Soil silt (\%) & $56.3 \pm 10.0$ & 35.1 & 77.9 & n.s. & n.s. \\
\hline Soil clay $(\%)$ & $8.0 \pm 3.8$ & 3.9 & 24.7 & n.s. & n.s. \\
\hline \multicolumn{6}{|l|}{ Light } \\
\hline Canopy openness (\%) & $18.95 \pm 6.69$ & 6.60 & 40.71 & $-0.36^{* *}$ & $0.47 * * *$ \\
\hline Herb-layer cover $(\%)$ & $74 \pm 11$ & 50 & 95 & $0.36 * *$ & n.s. \\
\hline Moos-layer cover $(\%)$ & $7 \pm 10$ & 0 & 50 & $-0.45 * * *$ & $0.82 * * *$ \\
\hline \multicolumn{6}{|c|}{ Species richness (number of species per plot) } \\
\hline Herb-layer vascular plants & $28 \pm 9$ & 12 & 48 & - & $-0.46^{* * *}$ \\
\hline Ground-dwelling bryophytes & $4 \pm 2$ & 0 & 11 & $-0.46^{* * *}$ & - \\
\hline
\end{tabular}

Note: ${ }^{*} P<0.05, * * P<0.01,{ }^{* * *} P<0.001$, n.s. - not significant.

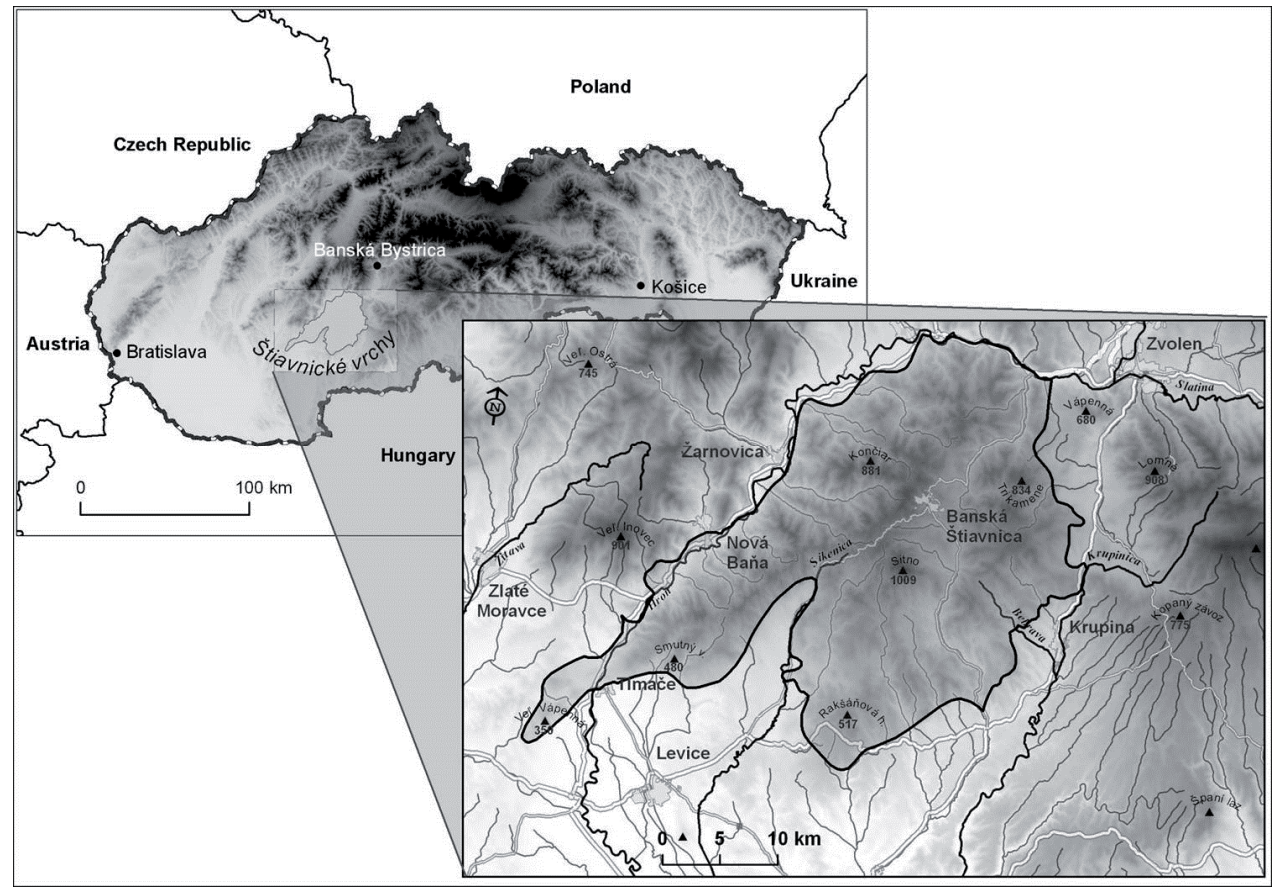

Figure 1. Map of the study area (Štiavnické vrchy Mts.) within Slovakia. 
plants (without tree species juveniles) and ground-dwelling bryophytes (mosses and liverworts using soil as a substrate). Species richness (i.e., number of species per sampling plot as a measure of alpha diversity) was determined for each plant functional group.

The total percentage of herb-layer and moss-layer cover was visually estimated at each plot. The geographical coordinates (WGS-84), altitude and aspect of the plots were measured with the Garmin GPSmap $60 \mathrm{CSx}$ equipment (Garmin Inc., Kansas, US) and slope inclination with the Suunto PM5/1520PC clinometer (Suunto, FI). Both the potential annual direct incident radiation index (hereinafter called radiation) and heat load index were calculated from slope inclination, aspect and latitude according to McCune and Keon (2002; Equation no. 3). Radiation index represents the amount of solar energy that might potentially get to the vegetation (MJ. $\mathrm{cm}^{-2} \cdot \mathrm{yr}^{-1}$ ). It is symmetrical along north-south line (i.e., east aspect has the same value as west) and maximum values are predicted for south slopes. In contrast, heat load index is calculated with aspect folded about the NE-SW line as it presumes highest temperatures on steep SW-facing slopes. Although the calculation does not take into account cloud cover, local differences in atmospheric transmissivity or shading by adjacent topography and vegetation, both topographic indices represent useful methods for quantifying of the solar energy input into habitats. The light conditions were assessed from hemispherical photographs taken at a height of $1 \mathrm{~m}$ above the ground in the centre of the plot. A Canon EOS 350D digital camera (Canon, JP) equipped with a Sigma 4.5 $\mathrm{mm}$ F2.8 EX DC lens (Sigma, JP) with a field of view of $180^{\circ}$ (fish-eye lens) was used. Black-and-white transformation of photographs used the automatic threshold algorithm on the blue colour channel in SideLook 1.1 software. The setting with blue channel enables attainment of higher local contrast between classified vegetation canopy (tree crowns) and the sky. Canopy openness expressing the percentage of open sky seen from beneath a forest canopy was calculated with Gap Light Analyser 2.0 program (Frazer et al. 1999). Soil samples were randomly taken in three places within each plot from the uppermost mineral horizon $(0-5 \mathrm{~cm}$ depth, litter removed) and mixed to form a single sample per plot in order to reduce the soil heterogeneity. Samples were dried at ambient laboratory temperature, crushed and passed through a $2 \mathrm{~mm}$ sieve. Soil analyses were performed on air-dried samples following standard protocols. The particle-size distribution (content of sand, silt and clay) was assessed with the Laser analyser (Fritsch GmbH Analysette 22; DE), in which ultrasound and sodium hexametaphosphate $\left[\left(\mathrm{NaPO}_{3}\right)_{6}\right]$ were applied for disaggregating. Soil $\mathrm{pH}$ was measured in a distilled water solution (soil/water ratio of 1/2.5) using a $\mathrm{pH}$ meter (WTW Inolab $\mathrm{pH} 720, \mathrm{DE})$. The total carbon $(\mathrm{C})$ and total nitrogen $(\mathrm{N})$ content were determined by an elemental analyser NCS-FLASH 1112 (CE Instruments, UK). Plant-available phosphorus (P) was extracted by the Mehlich II method, exchangeable cations of potassium $(\mathrm{K})$, calcium $(\mathrm{Ca})$ and magnesium $(\mathrm{Mg})$ in $0.1 \mathrm{M} \mathrm{BaCl}_{2}$-solution and determined using an atomic absorption spectrophotometer. The exchangeable aluminium (Al) ions were obtained by titration in $1 \mathrm{M} \mathrm{KCl}$ solution.

\section{Statistical analysis}

All the statistical analyses were computed by the R software (version 3.0.2, R Development Core Team 2013) and CANOCO for Windows package (version 4.5, Microcomputer Power, Ithaca, NY, US). The initial set of explanatory variables included all environmental factors that were recorded and/or calculated for each plot (Table 1). Principal components analysis (PCA) was performed to avoid collinearity among soil chemical factors. Soil $\mathrm{pH}$, concentrations of $\mathrm{K}$, $\mathrm{Ca}, \mathrm{Mg}$ and $\mathrm{Al}$ were thus associated with the PCA axis 1 (soil $\mathrm{pH} /$ base saturation gradient), total $\mathrm{C}$ and $\mathrm{N}$ content with the PCA axis 2 (organic matter) and concentration of $\mathrm{P}$ with the PCA axis 3 (Table 2). Site scores at the three principal components axes explaining the largest part of the variation in the data $(83.2 \%)$ were used in further analyses instead of the measured soil chemical factors. Herb-layer cover and species richness were used as additional explanatory variables for ground-dwelling bryophyte patterns and vice versa. Details on the Spearman rank correlations among explanatory variables are given in Appendix 1.

Relationships between species richness of both plant functional groups and initial environmental variables were quantified by Spearman correlation coefficients. More complex insight into the variation of species richness and its response to influence environmental variables was modelled using the generalised linear model (GLM). Since the dependent variable represents count data, Poisson error distribution and logarithmic link function were used in model specifications. The minimal adequate model was calculated with backward stepwise selection based on the Akaike information criterion, following recommendation of Johnson and Omland (2004). Statistical significance of each variable in the minimal model was tested by $\chi^{2}$ statistic. Multicollinearity was recorded for both final GLMs using the variance inflation factor.

Canonical correspondence analysis (CCA) was used to identify how vegetation composition of herb-layer vascular plants and ground-dwelling bryophytes is affected by environmental factors. Suitability of the CCA method was supported by results of detrended correspondence analysis, which produced a length of first axis gradient of 3.56 standard units for herb-layer vascular plants and 3.85 standard units for ground-dwelling bryophytes. Species cover values were log-transformed and rare species were down-weighted. Forward selection procedure was applied to create the most parsimonious set of variables that significantly contribute to the explained variation. Each variable entered into the analysis separately without covariables and the significance of its gross effect $(P<0.05)$ was assessed using a Monte Carlo permutation test with 999 unrestricted permutations. Net effect subsequently expressed only variation explained by target (single explanatory) variable using the other as covariables.

\section{Results}

Altogether 225 plant species including 190 herb-layer vascular plants and 35 ground-dwelling bryophytes were recorded in deciduous oak forests. The most frequent species 
Table 2. Correlation values between the PCA axes and the soil chemical variables. Bold values (loadings $>0.7$ ) indicate the most important factors for particular axis.

\begin{tabular}{lccc}
\hline & PCA Axis1 & PCA Axis2 & PCA Axis3 \\
\cline { 2 - 4 } Interpretation of PCA axes & Soil pH/base saturation gradient & Organic matter & Phosphorus \\
\hline Explained variation & $48.4 \%$ & $23.2 \%$ & $11.6 \%$ \\
\hline Soil pH & $\mathbf{0 . 8 6}$ & -0.29 & 0.15 \\
Total Carbon & 0.25 & $\mathbf{0 . 9 5}$ & -0.09 \\
Total Nitrogen & 0.55 & $\mathbf{0 . 8 1}$ & -0.11 \\
Soil Phosphorus & 0.47 & 0.09 & $\mathbf{0 . 8 4}$ \\
Soil Potassium & $\mathbf{0 . 7 6}$ & 0.15 & 0.06 \\
Soil Calcium & $\mathbf{0 . 8 6}$ & -0.13 & -0.19 \\
Soil Magnesium & $\mathbf{0 . 7 9}$ & -0.24 & -0.36 \\
Soil Aluminium & $\mathbf{- 0 . 8 1}$ & 0.35 & 0.05 \\
\hline
\end{tabular}

Table 3. Generalized linear models of local species richness for herb-layer vascular plants and ground-dwelling bryophytes with cumulative percentage deviance explained by the model. The plus/minus symbols refer to the regression coefficient of the variable in the model.

\begin{tabular}{lc}
\hline Species group/Predictor & $\begin{array}{c}\text { Cumulative deviance } \\
\text { explained }\end{array}$ \\
\hline Herb-layer vascular plants & $14.7 \%$ \\
- Canopy openness & $19.8 \%$ \\
- Canopy openness ${ }^{2}$ & $38.3 \%$ \\
+ Altitude & $59.1 \%$ \\
+ Soil pH/base saturation gradient & $62.2 \%$ \\
+ Phosphorus & \\
Ground-dwelling bryophytes & $19.0 \%$ \\
+ Canopy openness & $23.7 \%$ \\
+ Heat load & $28.8 \%$ \\
- Heat load & $43.3 \%$ \\
- Soil $\mathrm{pH} / \mathrm{base} \mathrm{saturation} \mathrm{gradient}$ & \\
\hline
\end{tabular}

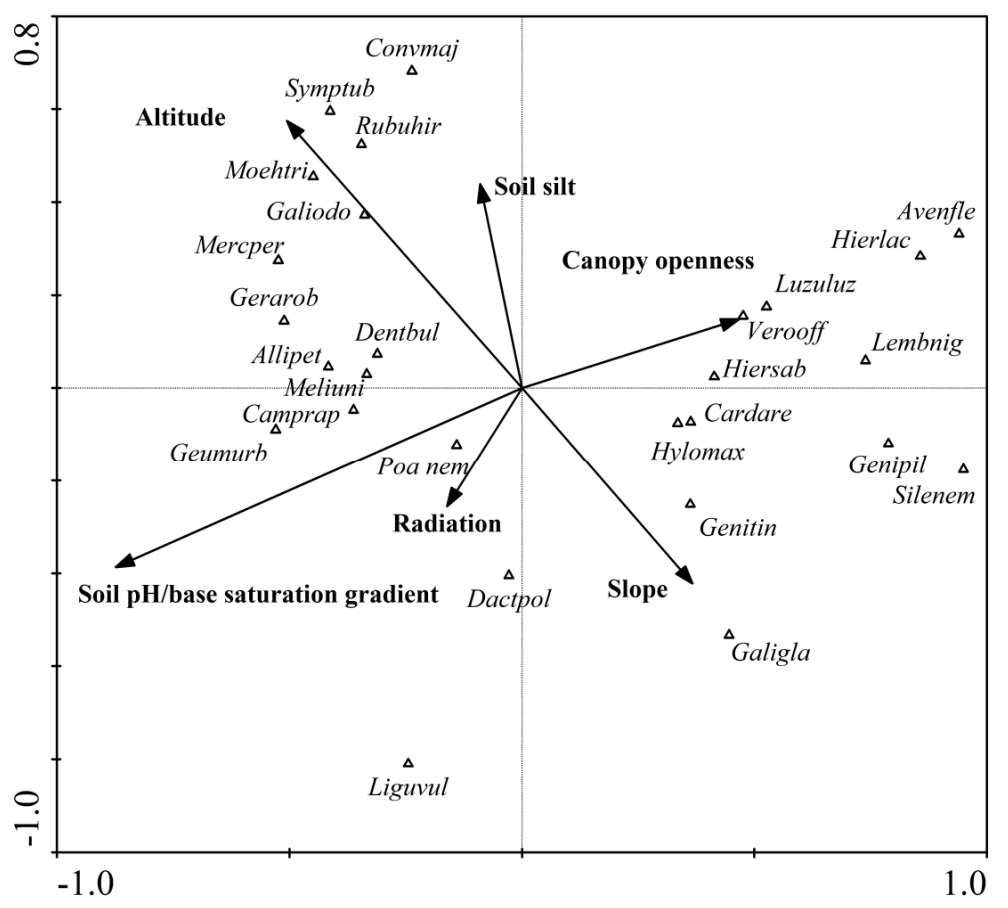

Figure 2. CCA biplot with vascular plant species (fit $\geq 22 \%$ ) and significant environmental variables identified in forward selection procedure (Table 4). First two CCA ordination axes are shown. Abbreviations of species names: Allipet - Alliaria petiolata, Avenfle-Avenella flexuosa, Camprap - Campanula rapunculoides, Cardare - Cardaminopsis arenosa, Convmaj Convallaria majalis, Dactpol - Dactylis polygama, Dentbul - Dentaria bulbifera, Galigla - Galium glaucum, Galiodo Galium odoratum, Genipil - Genista pilosa, Genitin - Genista tinctoria, Gerarob - Geranium robertianum, Geumurb Geum urbanum, Hierlac - Hieracium lachenalii, Hiersab - Hieracium sabaudum, Hylomax - Hylotelephium maximum, Lembnig - Lembotropis nigricans, Liguvul - Ligustrum vulgare, Luzuluz - Luzula luzuloides, Meliuni - Melica uniflora, Mercper - Mercurialis perennis, Moehtri - Moehringia trinervia, Poa nem - Poa nemoralis, Rubuhir - Rubus hirtus, Silenem - Silene nemoralis, Symptub - Symphytum tuberosum, Verooff-Veronica officinalis. 
Table 4. Variation in species composition of herb-layer vascular plants and ground-dwelling bryophytes in deciduous oak forests explained by each significant variable identified in CCA with Monte Carlo permutation test and forward selection. Explained variance is shown as percentage of total inertia. Gross and net effect represents explained variance by single variable separately and with using the other as covariables, respectively.

\begin{tabular}{|c|c|c|c|c|}
\hline Species group/Predictor & Gross effect $(\%)$ & Significance & Net effect $(\%)$ & Significance \\
\hline \multicolumn{5}{|l|}{ Herb-layer vascular plants } \\
\hline Soil $\mathrm{pH} / \mathrm{base}$ saturation gradient & 10.57 & $* * *$ & 3.96 & $* * *$ \\
\hline Altitude & 4.62 & $* * *$ & 3.79 & $* * *$ \\
\hline Slope & 4.10 & $* * *$ & 3.44 & $* * *$ \\
\hline Canopy openness & 3.16 & $* * *$ & 2.19 & $*$ \\
\hline Radiation & 2.82 & $* *$ & 2.19 & $*$ \\
\hline Soil silt & 2.23 & $*$ & 0.87 & n.s. \\
\hline \multicolumn{5}{|l|}{ Ground-dwelling bryophytes } \\
\hline Radiation & 11.34 & $* * *$ & 6.55 & $* * *$ \\
\hline Canopy openness & 5.39 & $* *$ & 2.46 & n.s. \\
\hline
\end{tabular}

Note: $* \mathrm{P}<0.05,{ }^{*} \mathrm{P}<0.01,{ }^{* * *} \mathrm{P}<0.001$, n.s. - not significant.

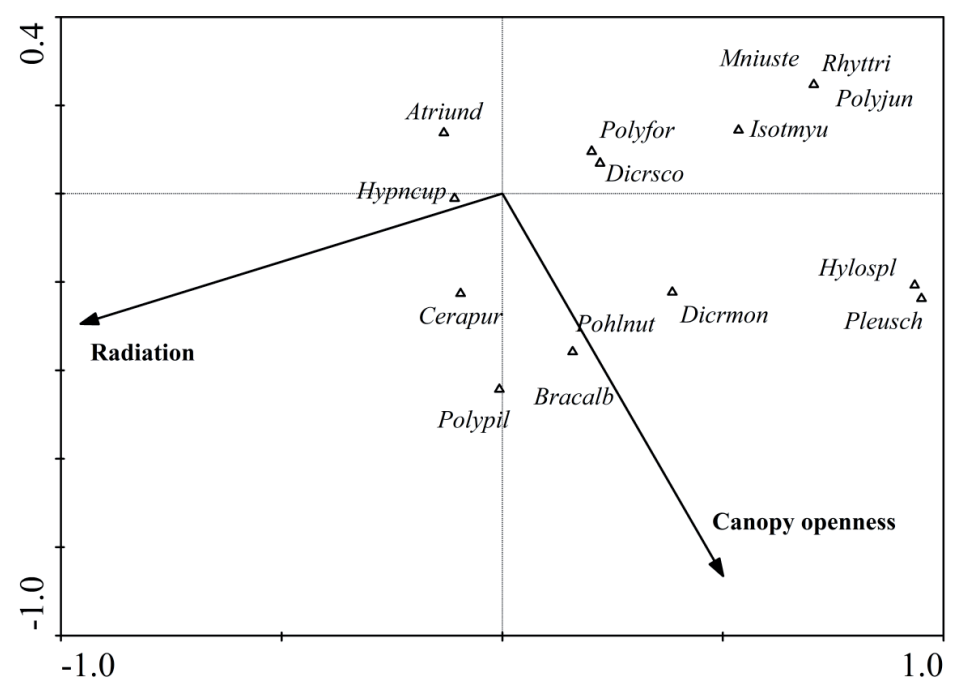

Figure 3. CCA biplot with bryophyte species (fit $\geq 10 \%$ ) and significant environmental variables identified in forward selection procedure (Table 4). First two CCA ordination axes are shown. Abbreviations of species names: Atriund - Atrichum undulatum, Bracalb - Brachythecium albicans, Cerapur - Ceratodon purpureus, Dicrmon - Dicranum montanum, Dicrsco Dicranum scoparium, Hylospl - Hylocomium splendens, Hypncup - Hypnum cupressiforme, Isotmyu - Isothecium myurum, Mniuste Mnium stellare, Pleusch - Pleurozium schreberi, Pohlnut - Pohlia nutans, Polyfor - Polytrichum formosum, Polyjun - Polytrichum juniperinum, Polypil - Polytrichum piliferum, RhyttriRhytidiadelphus triquetrus. of the understorey found in more than $25 \%$ plots were predominantly common acidic-tolerant plants accompanied by mesophilous species (e.g., Cardaminopsis arenosa, Digitalis grandiflora, Genista tinctoria, Hylotelephium maximum, Hypericum perforatum, Lathyrus niger, Luzula luzuloides, Poa nemoralis, Pyrethrum corymbosum, Veronica chamaedrys, V. officinalis). Ground-dwelling bryophytes were generally less abundant at mesophilous sites, but their proportion increased in acidophilous oak forest stands which had moderate canopy openness. In contrast to vascular plants, only the ubiquitous pleurocarpous moss Hypnum cupressiforme without narrow substrate specialization and the tall acrocarpous moss Polytrichum formosum were found in more than $25 \%$ of the plots.

Environmental conditions of deciduous oak forests, which were favourable for species richness of bryophytes, did not correspond with those supporting higher vascular plant richness (Table 1). Bryophyte richness increased with increasing canopy openness, whereas heat load had a negative influence. The species richness of vascular plants was positively related to altitude and herb-layer cover, but we did not observe their relationship to bryophyte richness. Both plant functional types showed contrasting patterns to the set of soil edaphic variables, but no correlations were found with soil texture-related parameters. Acidic and nutrient-poor soils with higher availability of $\mathrm{Al}$ ions were positively correlated with the bryophyte richness, while Al concentration in soil solution reduced the vascular plant richness.

The GLM of the vascular plants explained $62.2 \%$ of variation in the species richness with only four independent variables retained in the minimal adequate model (Table 3). The set of main predictors encompassed canopy openness, altitude and soil $\mathrm{pH} /$ base saturation gradient explaining comparable proportion of total variation in richness pattern. The soil $\mathrm{P}$ had the lowest explanatory power. The quadratic term of canopy openness suggested a hump-shaped relationship between light transmission and species richness of vascular plants, while altitude, soil $\mathrm{pH} /$ base saturation gradient and phosphorus had a positive linear effect on it. The GLM of bryophyte richness was determined by a combination of canopy openness, soil $\mathrm{pH} /$ base saturation gradient and heat load which all accounted for $43.3 \%$ of its variation (Table 3 ). The canopy openness showed positive and soil $\mathrm{pH} /$ base saturation negative impact on species richness of bryophytes, but 
the quadratic heat load term received also significant support. The values of the variance inflation factor in GLMs of vascular plants (1.05-1.43) and bryophytes (1.13-2.94) indicated a lack of multicollinearity in the explanatory variables included in the models.

The CCA analysis using forward selection identified six predictors (soil $\mathrm{pH} /$ base saturation gradient, altitude, slope, canopy openness, radiation, soil silt) that significantly influenced the herb-layer species composition pattern (Table 4 , Fig. 2). The highest amount of variation in species data was explained by soil $\mathrm{pH} /$ base saturation gradient and topography related predictors. Acidophilous species related to relatively open canopy stands (e.g., Avenella flexuosa, Hieracium lachenalii, Luzula luzuloides) present in one part of the ordination space were in contrast with meso- to eutrophic species of more shaded sites in the opposite part of the diagram (e.g., Alliaria petiolata, Geum urbanum, Melica uniflora). Species of steep slopes at lower altitudes (Galium glaucum, Genista tinctoria, Hylotelephium maximum) contrasted with species preferring gentle slopes or flat surfaces with deeper soils (Convallaria majalis, Galium odoratum, Symphytum tuberosum; Fig. 2). The CCA analysis further revealed that radiation and canopy openness were the main factors affecting species composition of ground-dwelling bryophytes (Table 4 , Fig. 3). A group of light-demanding species (Brachythecium albicans, Ceratodon purpureus, Polytrichum piliferum) was related to more xeric and open canopy sites, whereas the shade-tolerant species (Isothecium myurum, Mnium stellare, Polytrichum formosum) occurred on mesic sites (Fig. 3).

\section{Discussion}

\section{Herb-layer vascular plants}

Our study showed significant changes in species richness of vascular plants related to canopy openness in deciduous oak forests. The observed hump-shaped relationship is consistent with species richness study of mixed deciduous forests in northwest Germany (Schuster and Diekmann 2005). Light availability may directly and indirectly determine species richness of vascular plants through its effect on species pool (Ewald 2008) and habitat productivity (Axmanová et al. 2012). Higher light availability tends to be coupled with higher productivity of herb layer mainly at intermediate and basic parts of the $\mathrm{pH}$ gradient, which may lead to increase of species richness (Axmanová et al. 2012). However, the highes light availability values in our data (canopy openness more than $26 \%$ ) were closely linked with highly acidic soils (mean $\mathrm{pH}$ value 4.29), and this fact resulted in subsequent decline of species richness. Härdtle et al. (2003) also found that the importance of light conditions in temperate deciduous forests increases towards oligotrophic sites. The soil $\mathrm{pH} / \mathrm{b}$ ase saturation gradient (and also soil $\mathrm{pH}$, results not shown) had a positive effect on richness of herb-layer vascular plants (Table 3 , Appendix 2). Lower species richness on highly acidic soils is attributed to extensive injury of root cell membranes by hydrogen ions accompanied by reduced nutrient uptake and inhibition of root cell division by rising solubility of toxic elements such as aluminium (Andersson 1988, Marschner 1991). If $\mathrm{pH}$ exceeds threshold values for such soils (Tyler 2003), aluminium toxicity is neutralised and nutrient availability becomes more favourable. A positive response of species richness to $\mathrm{pH}$ is in agreement with conclusions for temperate regions of Europe reported by Pärtel (2002). The current prevalence of calcicole species in regional floras results from their evolutionary history, as most of the central European floras had their origins in areas with high soil $\mathrm{pH}$ (Pärtel 2002, Chytrý et al. 2003). However, positive species richness-pH relationship cannot be generalised because a unimodal response was already proved in broad-leaved deciduous forest as well (e.g., Schuster and Diekmann 2005). The hump-shaped pattern, typical primarily for herbaceous plant communities (Schuster and Diekmann 2003), seems to be dependent on inclusion of extreme habitats on the $\mathrm{pH}$ gradient (Dupré et al. 2002).

The soil $\mathrm{P}$ was revealed as additional driving force for species richness pattern of vascular plants. An increase in species richness of herb-layer vascular plants with concentration of plant-available $\mathrm{P}$ has already been identified in oakdominated forests by Hofmeister et al. (2009), although the opposite pattern has more often been shown in herb layer of temperate forests (Dumortier et al. 2002, Hrivnák et al. 2015). High soil P promotes vigorous growth of competitive species and this asymmetric competition can reduce species diversity. The soils developed on volcanic rocks are usually P-rich, but the relatively low P supply found in our case $\left(31.5 \mathrm{mg} . \mathrm{kg}^{-1}\right.$; Table 1) is most likely caused by the occurrence of rhyolites and by chemical fixation of $\mathrm{P}$ in the aluminium- and iron phosphates at low $\mathrm{pH}$ values. Therefore, increasing species richness was still recorded on relatively P-poor soils compared to other sites of broad-leaved forests in Central Europe (e.g., Hofmeister et al. 2009, Axmanová et al. 2012).

Previous research at a local and regional scale showed two common responses of plant species richness to altitude, i.e., a monotonically decreasing trend and a hump-shaped curve with highest diversity at intermediate altitudes and low diversity at both ends of the elevation gradient (e.g., Rahbek 2005, Bacaro et al. 2008). The unimodal response appears to be universal and other linear trends can be addressed to habitat-related biases such as restricted length of analysed gradient. It has been also found that size and composition of local species pool (Hrivnák et al. 2014) and environmental conditions expressed through the effect of several often covarying factors vary along the altitudinal gradient (Rahbek 2005). The positive effect of the short altitudinal gradient $(330-805 \mathrm{~m})$ revealed in our study presumably reflects better growth conditions at higher altitudes (submontane zone) of this region, where both increasing precipitation and prevalence of only slightly acidic and neutral soil substrates jointly support higher herb-layer productivity. Positive correlation between altitude and herb layer cover (Appendix 1) indicates this assumption. An additional explanation for the higher species richness at higher altitudes could be associated with the spatial mass effect (Shmida and Wilson 1985). Oak forests at the upper end of the altitudinal gradient often form only patches in a mosaic with other more mesic forests and herb 
layer thus can be enriched by several mesophilous species (Fig. 2).

Most of the compositional variability in the species data was explained by topographic and edaphic variables. They are generally considered to be good environmental predictors of vegetation patterns in deciduous oak forests at local scale (e.g., Szymura and Szymura 2011, Reczyńska 2015). These factors also coincide with major gradients responsible for species composition variation of other temperate broad-leaved forests in Central Europe (Ellenberg 2009). Topographic variables, such as altitude, slope inclination and radiation, have no direct physiological effect on plant assemblage, but they tend to be significant controls of the distribution in abiotic resources and conditions (soil nutrients and moisture availability, air temperature) that are important for plant growth (Rahbek 2005, Sabatini et al. 2014). The investigated oak forests commonly occur on south-facing steep slopes with skeletal soils. Their habitat preference thus significantly affects soil depth and water retention capacity which points out the role of topographic variables. Soil pH gradient accompanied by closely related geological bedrock and soil chemistry properties (base-saturation complex) are usually one of the most important drivers in vegetation patterns of deciduous oak forests at local scale. The observed lower explanatory power is probably a consequence of limited $\mathrm{pH}$ gradient and a predominance of acidic substrates in the study area, which led to increased relevance of landscape topography.

\section{Ground-dwelling bryophytes}

Species richness of ground-dwelling bryophytes showed contrasting patterns compared to herb-layer vascular plants in relation to most of the predictors, which corresponds well with other species diversity studies performed in deciduous and evergreen forests (e.g., Ingerpuu et al. 2003, Bacaro et al. 2008). These diverse responses to environmental gradients are usually explained by distinct life history traits of bryophytes, which make them successful in growth within various terrestrial habitats (Brown and Bates 1990, Cornelissen et al. 2007, Bates 2009).

The GLM for species richness of ground-dwelling bryophytes stressed the role of canopy openness and heat load index, which considerably affect light quantity and quality, but also temperature, humidity and radiation in the forest understorey. Since these variables are considered to be crucial for bryophyte assemblages (Márialigeti et al. 2009), the composition of a bryophyte community results from the effective adaptation of species to different microclimatic conditions. Although a dense canopy closure of vascular plants partially improves microclimate, negative shading impact usually overwhelms these favourable effects of temperature and moisture regimes (van der Wal et al. 2005). The positive effect of light availability on bryophyte richness in temperate mixed forests has also been demonstrated by Tinya et al. (2009). Bryophytes belong to primary producers of ecosystems and the rise in their species richness may be a consequence of their ability to use energy input (Raabe et al. 2010). The hump-shaped response of species richness to heat load index might be caused by local coexistence of acrocarpous and pleurocarpous mosses. Heat load index generally represents mediated response to a drought stress (Pausas and Austin 2001), i.e., the steep southwards facing slopes reduce water availability that finally imposes an important physiological constraint. This physiological limit is more pronounced for tall pleurocarpous mosses (Kubešová and Chytrý 2005), whereas acrocarpous mosses (especially those forming dense cushions) showed a higher desiccation tolerance (van der Hoeven and During 1997). The steep but less insolated habitats (species richness peak at the heat load index values 0.66 and 0.68 corresponds to the north-west and east facing slopes, respectively) promote existence of litterless soil patches and at the same time, support microclimatic conditions favourable also for development of pleurocarpous mosses. Similar unimodal relationship of bryophyte richness with soil moisture-related index was also found by Pausas (1994) in Pyrenean Pinus sylvestris dominated forests.

The negative effect of soil $\mathrm{pH} /$ base saturation gradient on bryophyte species richness is consistent with previous observations (Kellner 1993, Ingerpuu et al. 2003). Although increased availability of nutrients may facilitate the presence of some pleurocarpous or acrocarpous species (Kubešová and Chytrý 2005), and several of them were also recorded in the studied oak forests (e.g., Hylocomium splendens, Rhytidiadelphus triquetrus, Weissia controversa), overall bryophyte richness was significantly reduced along increasing soil $\mathrm{pH} /$ base saturation gradient. Its lower predictive role in variation of bryophyte species richness suggests differences between the bryophytes and vascular plants either in ecophysiological limits (Büscher et al. 1990, Bates 1992, Tyler 2003) or in constraints of Central European species pool at the acidic end of the $\mathrm{pH}$ gradient (Merunková and Chytrý 2012). A negative response to the $\mathrm{pH}$ gradient has less often been noted, although the presence of a well-developed moss layer was commonly reported from acidophilous oak forests (e.g., Reczyńska 2015). The lower species richness in less acidic, nutrient richer sites could be referred to several, not mutually exclusive mechanisms. These conditions favour mainly fast-growing herbaceous species that in more productive habitats readily outcompete tiny ground-dwelling bryophytes. Light asymmetric competition acts in combination with negative effects of herbaceous organic matter and deciduous litter. They represent physical barriers for potential establishment of bryophytes and can inhibit their successful growth by shading (Rincon 1988). However, we did not find statistical evidence that species rich bryophyte layer prospers better under the sparse herb-layer cover, which might be explained by the truncated gradient of herb-layer cover that was tested (in our dataset the herb-layer was relatively dense with minimal total cover of $50 \%$, Table 1 ).

Variation in species composition of ground-dwelling bryophytes was controlled by radiation and canopy openness. This is in agreement with previous studies that reported significant role of light availability and light-induced factors on composition or cover of local bryophyte assemblages in temperate forests (e.g., Márialigeti et al. 2009, Tinya et al. 2009, Raabe et al. 2010). Overall habitat conditions of oak 
forests affect the relative density of oak individuals and the shape of tree crowns (Longuetaud et al. 2008), which in turn modify light transmission through the forest overstorey. Oakdominated forests frequently form moderate to open-canopy stands (Ádam et al. 2013, Reczyńska 2015), but their understorey layer tends to have strong spatial fine-scale heterogeneity of light. Fine scale partitioning of light availability creates higher niche diversity and consequently promotes higher compositional variability of bryophytes. Distribution of ground-dwelling bryophytes in our study varied with soil $\mathrm{pH} /$ base saturation gradient and showed well-established relation of some individual species to a specific part of acidity or rather productivity gradient (e.g., affinity of Dicranella heteromalla, Polytrichum juniperinum and P. piliferum to nutrient-poor, highly acidic soils of $\mathrm{pH} 3.80-4.29$ ), but we did not confirm its general effect on species composition. These findings support results of Hokkanen (2006) that the $\mathrm{pH} / \mathrm{cal}$ cium gradient was less important than other edaphic variables (mainly moisture availability) for compositional changes in bryophyte community.

Acknowledgements: We would like to thank A. Petrášová for identification of bryophytes. This research was supported by the Science Grant Agency of the Ministry of Education of the Slovak Republic and Slovak Academy of Sciences (VEGA 2/0027/13).

\section{References}

Ádám, R., P. Ódor and J. Bölöni. 2013. The effects of stand characteristics on the understory vegetation in Quercus petraea and $Q$. cerris dominated forests. Community Ecol. 14: 101-109.

Andersson, M. 1988. Toxicity and tolerance of aluminium in vascular plants. A review. Water Air Soil Pollut. 39: 439-462.

Attiwill, P.M. and M. Adams. 1993. Nutrient cycling in forests. New Phytol. 124: 561-582.

Augusto, L., J.-L. Dupouey and J. Ranger. 2003. Effects of tree species on understory vegetation and environmental conditions in temperate forests. Ann. For. Sci. 60: 823-831.

Augusto, L., J. Ranger, D. Binkley and A. Rothe. 2002. Impact of several common tree species of European temperate forests on soil fertility. Ann. For. Sci. 59: 233-253.

Axmanová, I., M. Chytrý, D. Zelený, C.F. Li, M. Vymazalová, J. Danihelka, M. Horsák, M. Kočí, S. Kubešová, Z. Lososová, Z. Otýpková, L. Tichý, V.B. Martynenko, E.Z. Baisheva, B. Schuster and M. Diekmann. 2012. The species richness-productivity relationship in the herb layer of European deciduous forests. Global Ecol. Biogeogr. 21: 657-667.

Bacaro, G., D. Rocchni, I. Bonini, M. Marignani, S. Maccherini and A. Chiarucci. 2008. The role of regional and local scale predictors for plant species richness in Mediterranean forests. Plant Biosyst. 142: 630-642.

Barbier, S., F. Gosselin and P. Balandier. 2008. Influence of tree species on understory vegetation diversity and mechanisms in volved - A critical review for temperate and boreal forests. For Ecol. Manag. 254: 1-15.

Bates, J.W. 1992. Mineral nutrient acquisition and retention by bryophytes. J. Bryol. 17: 223-240.
Bates, J.W. 2009. Mineral nutrition and substratum ecology. In: Goffinet, B. and A.J. Shaw (eds.), Bryophyte Biology. Cambridge Univ. Press, Cambridge. pp. 299-356.

Brown, D.H. and J.W. Bates. 1990. Bryophytes and nutrient cycling. Bot. J. Linn. Soc. 104: 129-147.

Büscher, P., N. Koedam and D. van Speybroeck. 1990. Cationexchange properties and adaptation to soil acidity in bryophytes. New Phytol. 115: 177-186.

Chytrý, M., L. Tichý and J. Roleček. 2003. Local and regional patterns of species richness in central European vegetation types along the $\mathrm{pH} /$ calcium gradient. Folia Geobot. 38: 429-442.

Cornelissen, J.H.C., S.I. Lang, N.A. Soudzilovskaia and H.J. During. 2007. Comparative cryptogam ecology: a review of bryophyte and lichen traits that drive biogeochemistry. Ann. Bot. 99: 9871001 .

Dumortier, M., J. Butaye, H. Jacquemyn, N. van Camp, N. Lust and M. Hermy. 2002. Predicting vascular plant species richness of fragmented forests in agricultural landscapes in central Belgium. For. Ecol. Manag. 158: 85-102.

Dupré, C., C. Wessberg and M. Diekmann. 2002. Species richness in deciduous forests: effects of species pools and environmental variables. J. Veg. Sci. 13: 505-516.

Ellenberg, H. 2009. Vegetation Ecology of Central Europe. Cambridge Univ. Press, Cambridge.

Ewald, J. 2008. Plant species richness in mountain forests of the Bavarian Alps. Plant Biosyst. 142: 594-603.

Frazer, G.W., C.D. Canham and K.P. Lertzman. 1999. Gap Light Analyzer (GLA), Version 2.0. Imaging software to extract canopy structure and gap light transmission indices from true-colour fisheye photographs, user's manual and program documentation. Simon Fraser Univ., Burnaby, British Columbia.

Gilliam, F.S. 2007. The ecological significance of the herbaceous layer in temperate forest ecosystems. BioScience 57: 845-858.

Härdtle, W., G. von Oheimb and C. Westphal. 2003. The effects of light and soil conditions on the species richness of the ground vegetation of deciduous forests in northern Germany (SchleswigHolstein). For. Ecol. Manag. 182: 327-338.

Hofmeister, J., J. Hošek, M. Modrý and J. Roleček. 2009. The influence of light and nutrient availability on herb layer species richness in oak-dominated forests in central Bohemia. Plant Ecol. 205: 57-75.

Hokkanen, P. 2006. Environmental patterns and gradients in the vascular plants and bryophytes of eastern Fennoscandian herb-rich forests. For. Ecol. Manag. 229: 73-87.

Hrivnák, R., D. Gömöry, M. Slezák, K. Ujházy, R. Hédl, B. Jarčuška and M. Ujházyová. 2014. Species richness pattern along altitudinal gradient in Central European beech forests. Folia Geobot. 49: 425-441.

Hrivnák, R., M. Slezák, B. Jarčuška, I. Jarolímek and J. Kochjarová. 2015. Native and alien plant species richness response to soil nitrogen and phosphorus in temperate floodplain and swamp forests. Forests 6: 3501-3513.

Ingerpuu, N., K. Vellak, J. Liira and M. Pärtel. 2003. Relationships between species richness patterns in deciduous forests at the north Estonian limestone escarpment. J. Veg. Sci. 14: 773-780.

Johnson, J.B. and K.S. Omland. 2004. Model selection in ecology and evolution. Trends Ecol. Evol. 19: 101-108.

Kellner, O. 1993. Effects on associated flora of sylvicultural nitrogen fertilization repeated at long intervals. J. Appl. Ecol. 30: 563574. 
Kubešová, S. and M. Chytrý. 2005. Diversity of bryophytes on treeless cliffs and talus slopes in a forested central European landscape. J. Bryol. 27: 35-46.

Longuetaud, F., T. Seifert, J.-M. Leban and H. Pretzsch. 2008. Analysis of long-term dynamics of crown of sessile oaks at the stand level by means of spatial statistics. For. Ecol. Manag. 225: 2007-2019.

Lundholm, J.T. 2009. Plant species diversity and environmental heterogeneity: spatial scale and competing hypotheses. J. Veg. Sci. 20: 377-391.

Marhold, K. and F. Hindák (eds.) 1998. Checklist of Non-vascular and Vascular Plants of Slovakia. Veda, Bratislava.

Márialigeti, S., B. Németh, F. Tinya and P. Ódor. 2009. The effects of stand structure on ground-floor bryophyte assemblages in temperate mixed forests. Biodiv. Conserv. 18: 2223-2241.

Marschner, H. 1991. Mechanisms of adaptation of plants to acid soils. Plant Soil 134: 1-20.

McCune, B. and D. Keon. 2002. Equations for potential annual direct incident radiation and heat load. J. Veg. Sci. 13: 603-606.

Merunková, K. and M. Chytrý. 2012. Environmental controls of species richness and composition in upland grasslands of the southern Czech Republic. Plant Ecol. 213: 591-602.

Pärtel, M. 2002. Local plant diversity patterns and evolutionary history at regional scale. Ecology 83: 2361-2366.

Pausas, J.G. 1994. Species richness patterns in the understorey of Pyrenean Pinus sylvestris forest. J. Veg. Sci. 5: 517-524.

Pausas, J.G. and M.P. Austin. 2001. Patterns of plant species richness in relation to different environments: an appraisal. J. Veg. Sci. 12: $153-166$.

Proctor, M.C.F. 1981. Physiological ecology of bryophytes. Adv. Bryol. 1: 79-166.

Proctor, M.C.F. and Z. Tuba. 2002. Poikilohydry and homoihydry: antithesis or spectrum of possibilities? New Phytol. 156: 327349.

Raabe, S., J. Müller, M. Manthey, O. Dürhammer, U. Teuber, A. Göttlein, B. Förster, R. Brandl and C. Bässler. 2010. Drivers of bryophyte diversity allow implications for forest management with a focus on climate change. For. Ecol. Manag. 260: 19561964.

Rahbek, C. 2005. The role of spatial scale and the perception of largescale species-richness patterns. Ecol. Lett. 8: 224-239.

Reczyńska, K. 2015. Diversity and ecology of oak forests in SW Poland (Sudetes Mts.). Phytocoenologia 45: 85-106.

Rincon, E. 1988. The effect of herbaceous litter on bryophyte growth. J. Bryol. 15: 209-217.

Sabatini, F.M., B. Jiménez-Alfaro, S. Burrascano and C. Blasi. 2014. Drivers of herb-layer species diversity in two unmanaged temperate forests in northern Spain. Community Ecol. 15: 147-157.
Schuster, B. and M. Diekmann. 2003. Changes in species density along the soil $\mathrm{pH}$ gradient - evidence from German plant communities. Folia Geobot. 38: 367-379.

Schuster, B. and M. Diekmann. 2005. Species richness and environmental correlates in deciduous forests of Northwest Germany. For. Ecol. Manag. 206: 197-205

Shmida, A. and M.V. Wilson. 1985. Biological determinants of species diversity. J. Biogeogr. 12: 1-20.

Szymura, T.H. and M. Szymura. 2011. Soil properties and light availability determine species richness and vegetation diversity in an overgrown coppice oak stand. Pol. J. Ecol. 59: 523-533.

Tilman, D. 2000. Causes, consequences and ethics of biodiversity. Nature 405: 208-211.

Tinya, F., S. Márialigeti, I. Király, B. Németh and P. Ódor. 2009. The effect of light conditions on herbs, bryophytes and seedlings of temperate mixed forests in Örség, Western Hungary. Plant Ecol. 204: 69-81.

Tyler, G. 2003. Some ecophysiological and historical approaches to species richness and calcicole/calcifuge behaviour - contribution to a debate. Folia Geobot. 38: 419-428.

van der Hoeven, E. and H.J. During. 1997. Positive and negative interactions in bryophyte populations. In: de Kroon, H. and J. van Groenendael (eds.), The Ecology and Evolution of Clonal Plants. Leiden, Backhuys, pp. 291-310.

van der Wal, R., I.S.K. Pearc and R.W. Brooker. 2005. Mosses and the struggle for light in a nitrogen-polluted world. Oecologia 142: $159-168$

Vockenhuber, E.A., C. Scherber, C. Langenbruch, M. Meißner, D. Seidel and T. Tscharntke. 2011. Tree diversity and environmental context predict herb species richness and cover in Germany's largest connected deciduous forest. Perspect. Plant Ecol. Evol. Syst. 13: 111-119.

Whigham, D.F. 2004. Ecology of woodland herbs in temperate deciduous forests. Ann. Rev. Ecol. Ev l. 35: 583-621.

Received December 20, 2015
Revised March 11, 2016

Accepted May 2, 2016

\section{Electronic supplements}

Appendix 1. Spearman rank correlation matrix among variables used in GLM and CCA for herb-layer vascular plants and ground-dwelling bryophytes.

Appendix 2. Visualization of the relationships between species richness and the most influential predictors according to Table 3.

The file may be downloaded from www.akademiai.com. 